\title{
Prediction of severe adverse maternal outcome in women admitted in obstetric ward using physiological and biochemical parameters
}

\author{
Reena Rani ${ }^{1 *}$, Sunita Bai Meena², C. P. Yadav³, Deepti Goswami', Reva Tripathi', \\ Asmita M. Rathore ${ }^{4}$
}

\begin{abstract}
${ }^{1}$ Department of Obstetrics and Gynecology, North Delhi Municipal Corporation Medical College and Hindu Rao Hospital, Delhi, India

${ }^{2}$ Department of Obstetrics and Gynecology, Mahatma Gandhi Medical College and Hospital, Jaipur, Rajasthan, India

${ }^{3}$ Department of Biostatistics, National Institute of Malaria Research, New Delhi, India

${ }^{4}$ Department of Obstetrics and Gynecology, Maulana Azad Medical College and associated hospitals, New Delhi, India
\end{abstract}

Received: 07 March 2019

Accepted: 02 April 2019

\section{*Correspondence:}

Dr. Reena Rani,

E-mail: dr.reena0310@gmail.com

Copyright: () the author(s), publisher and licensee Medip Academy. This is an open-access article distributed under the terms of the Creative Commons Attribution Non-Commercial License, which permits unrestricted non-commercial use, distribution, and reproduction in any medium, provided the original work is properly cited.

\section{ABSTRACT}

Background: To study physiological and biochemical parameters to predict serious adverse maternal outcomes and to develop risk score using above parameters.

Methods: This prospective study was conducted in 500 high risk pregnant women attending tertiary care teaching hospital. We noted physiological and biochemical parameters as soon as they were available .The primary outcome measures was "severe adverse maternal outcome(SAMO)" in form of one or more among mortality, near miss morbidity and ICU admissions.

Results: Out-off 500 women, severe adverse maternal outcomes were seen in 158 (31.6\%) women. Most common cause of near miss maternal morbidity was hypertensive disease of pregnancy $(62.7 \%)$ followed by major obstetric hemorrhage (18.9\%). There were 33(6.6\%) ICU admission, $23(4.6 \%)$ maternal death and $153(30.6 \%)$ near miss maternal morbidity. The most common cause of maternal death in our study was obstetric hemorrhage. The significant variables after multivariate analysis [temp, pulse, urine protein] were used to devise a Maternal early warning score (MEWS) based on physiological parameters at score value of $\geq 1 / 6$ was found to have sensitivity of $70 \%$ and specificity of $82 \%$ in predicting SAMO with AUROC of 0.76 . The significant laboratory parameters after multivariate analysis were blood urea, serum creatinine, serum bilirubin and liver enzymes. The obstetric risk score (Maternal risk prediction score MRPS) which incorporated of these laboratory parameters in addition to physiological parameters has sensitivity of $82 \%$ and specificity of $75 \%$ with AUROC 0.79 value $\geq 2 / 18$.

Conclusions: The addition of laboratotory parameters to physiological variables improves performance of risk score to predict SAMO.

Keywords: High risk pregnancy, Maternal mortality, Near miss morbidity

\section{INTRODUCTION}

Risk evaluation of patients admitted to ward is important to detect early signs of deterioration and enable appropriate and timely intervention. Vital sign or physiological parameter based early warning score (EWS) are used for this purpose and many of them are studied in obstetric population. ${ }^{1-4}$ The use of variables in a warning score is based more on consensus by clinicians than statistical validity and there is limited reporting of their use low and middle income countries (LMIC) where 
patient healthcare provider ratios, availability of parameters at admission and case mix may be different than in high income countries. ${ }^{5}$ These systems which are primarily recommended for acute risk of mortality but fail to identify women who have normal vital signs but still at risk of deterioration in near future. All admitted women undergo simple biochemical investigations and those at high risk of critical illness show changes in these parameters. ${ }^{6}$ However there is paucity of data regarding use of these biochemical parameters in obstetrics early warning score systems. These simple biochemical tests like hemogram, liver and kidney function test which are available in most of the secondary care centers could be helpful in early prediction of adverse outcomes in high risk patients. We used physiological parameters and bedside tests urine protein and hemoglobin which are relevant in Indian obstetric population to develop maternal early warning score (MEWS) and combined it with common biochemical investigations to develop Maternal risk prediction score (MRPS) to evaluate whether it improved performance of MEWS. Development of such a score which can be applied even by a general practitioner would be quite helpful in early identification of high risk women and timely referral to appropriate higher facilities which will result in reduction in poor outcome and provision of better clinical care.

The aims of the present study was to study the predictive strength of physiological [Temperature, pulse rate, respiratory rate (TPR), blood pressure (BP), neurological status], bedside tests hemoglobin, urine protein, haematological (white cell count, platelet count, prothrombin time) and biochemical parameters (blood urea,serum creatinine, serum bilirubin and liver enzymes alanine aminotransferase (ALT), aspartate aminotransferase (AST) for predicting adverse outcome in high risk obstetric patients. To compare the performance of risk score based on only physiological parameters and bedside tests MEWS to that based on both the physiological and laboratory parameters MRPS.

\section{METHODS}

This was a prospective observational study conducted at Department of Obstetrics and Gynaecology, Maulana Azad Medical College and associated Hospital, New Delhi. The sample size calculation used rule of thumb criteria. Since the main study outcomes (near miss and ICU admission, maternal death) are dichotomous with approximate $20 \%$ incidence and with 10 predictors in scoring system we would require around 100 events and thus need to enroll about 500 sick patients.

The inclusion criteria were- any high risk obstetric patient (women during pregnancy or within 42 days of delivery or termination of pregnancy) who has any one or more of the following-emergency admission, postoperative woman within 24 hours of surgery, admitted to obstetric high dependency unit, becomes sick when admitted in obstetrics ward. The women in active labour and women admitted directly to ICU were excluded.

The study protocol was approved by Institutional ethics committee and informed consent was obtained from all women, After complete clinical evaluation, physiological parameters were noted at admission and laboratory test results were noted when available within 24 hours.

\section{Physiological parameters}

- Temperature, pulse, respiration rate-recorded by nurse on duty

- $\quad$ Blood pressure (BP)-systolic and diastolic recorded by digital BP apparatus

- Urinary protein- considered positive if urine protein by dipstick is more than $1+$.

\section{Biochemical parameters were also noted once they are available after admission}

- Haemoglobin: normal range ${ }^{7}: 9.5-15.0 \mathrm{~g} / \mathrm{dL}$

- Total leucocyte count: normal range $^{7}$ : 5.9$16.9 \times 109 / \mathrm{L}$

- Platelet count: normal range ${ }^{7}$ : 1.46-4.29 X $100,000 / \mathrm{mm}^{3}$

- Prothrombin time: normal range ${ }^{8}$ : 9.6-12.9

- Serum bilirubin: normal range ${ }^{9}-0.1-1.1 \mathrm{mg} / \mathrm{dL}$

- liver enzymes ALT, AST): normal range9': 2-25 IU/L

- Blood Urea: normal range ${ }^{10}: 3-11 \mathrm{mg} / \mathrm{dL}$

- Serum creatinine: normal range ${ }^{10}: 0.4-0.9 \mathrm{mg} / \mathrm{dL}$

Women were managed by treating clinician as per routine departmental protocols. ICU admissions were done as per decision of treating physician and bed availability. Patients were followed up till discharge from the hospital.

The primary outcome measured was severe adverse maternal outcome (SAMO) which included occurrence of one or more among near miss morbidity, ICU admission and maternal death.

\section{Near miss morbidity was defined as following ${ }^{11}$}

- Major obstetric hemorrhage - Estimated blood loss > $2500 \mathrm{ml}$, or transfused five or more units of blood, or received treatment for coagulopathy

- Eclampsia.

- Acute Renal or Liver dysfunction- Acute onset of biochemical disturbance, urea $>40 \mathrm{mg} / \mathrm{dl}$ or $>15 \mathrm{mmol} / \mathrm{l}$, creatinine > 400mmol/l, AST, ALT > $200 \mathrm{U} / \mathrm{L}$.

- Cardiac arrest

- Pulmonary oedema- clinically diagnosed pulmonary oedema associated with acute breathlessness and Oxygen saturation $<95 \%$, requiring $\mathrm{O}^{2}$, diuretics or ventilation. 
- Acute respiratory dysfuntion- Requiring intubation or ventilation for $>60 \mathrm{~min}$ (not including duration of general anaesthetic)

- Coma-Unconscious>12 hours

- Cerebrovascular event- stroke, intracranial haemorrhage or infarction, dural venous sinus thrombosis, diagnosed on CT/MRI

- Anaphylactic shock- an allergic reaction resulting in collapse with severe hypotension, difficulty in breathing and swelling/rash

- Septicaemic shock- Refractory hypotension (systolic $\mathrm{BP}<80 \mathrm{~mm} / \mathrm{Hg}$ ) in association with evidence of infection. No other cause for decreased BP, Heart rate (HR) $90 \mathrm{bpm}$ or more, respiratory rate (RR) $>20 / \mathrm{min}$, total leukocyte count (TLC) $(<4000$ or $\left.>12000 / \mathrm{mm}^{3}\right)$, temperature $(>100.4 \mathrm{oF}$ or $<96.80 \mathrm{~F})$

- Anaesthetic problem- Aspiration, failed intubation, high spinal or epidural anaesthetic.

- Pulmonary embolism- Diagnosed clinically (RR > 20/ min, tachycardia, hypotension) or by Ventilation perfusion Scan (diagnosed as high probability) or by Computed Tomography scan (positive spiral chest) or Treated by heparin, thrombolysis or embolectomy.

\section{Statistical analysis}

Association of each possible predictor with SAMO was assessed using chi-square test followed by logistic regressing in bi-variable analysis. The variables which were found statistically association with SAMO at 5\% level of significance were considered for multivariable analysis and then step-wise logistic regression was used to find out final predictors of SAMO. All statistical calculation was done using Statistical software Stata 15.0 (StatCorp.). P-value less than 0.05 were considered as statistically significant.

Risk Score calculation: MEWS score is based on only physiological variables and bedside tests only while MRPS is based on both physiological as well as biochemical variables. For each predictors of SAMO in both the scores, regressing coefficient was calculated and divided by the smallest regression coefficient and round to nearest integer to get individual score for each predictor. Then risk score is calculated by adding each of the predictor after multiplying by their score. Predicted probability of SAMO at each value of risk score is calculated by the model then compared with observed probability of that score value from the data.

\section{RESULTS}

Five hundred women were included in this study. The mean age of the study population was $26.03 \pm 3.82$ years ranging from 19 to 40 years, The majority of the women were multiparous $(61.8 \%)$ and $58 \%$ were literate. The majority $(65 \%)$ of the women had adequate antenatal care in the hospital. Most of the women in study were antenatal $488(97.6 \%)$.

Table 1: Univariate analysis of demographic and predictor variables.

\begin{tabular}{|c|c|c|c|c|}
\hline & \multicolumn{2}{|l|}{ SAMO } & \multicolumn{2}{|l|}{ Unadjusted } \\
\hline & $\begin{array}{l}\text { No } \\
(n=342)\end{array}$ & $\begin{array}{l}\text { Yes } \\
(n=158)\end{array}$ & OR $(95 \%$ CI $)$ & P-value \\
\hline Age (yrs) & $25.8 \pm 3.6$ & $26.4 \pm 4.2$ & - & 0.132 \\
\hline \multicolumn{5}{|l|}{ Education } \\
\hline Illiterate & $131(38.3)$ & $79(50.0)$ & Ref. & 0.009 \\
\hline Schooling & $203(59.4)$ & $73(46.2)$ & $0.59(0.40$ to 0.89$)$ & 0.696 \\
\hline Graduate & $8(2.3)$ & $6(3.8)$ & $1.24(0.42$ to 3.71$)$ & \\
\hline \multicolumn{5}{|c|}{ Socio economic status } \\
\hline Upper & 0 & 0 & & \\
\hline Middle class & $42(12.3)$ & $28(17.7)$ & Ref & 0.105 \\
\hline Lower class & $300(87.7)$ & $130(82.3)$ & $0.65(0.39$ to 1.09$)$ & \\
\hline \multicolumn{5}{|l|}{ Parity } \\
\hline Nullipara & $129(37.7)$ & $67(42.9)$ & Ref & \\
\hline Multipara & $213(62.3)$ & $89(57.0)$ & $0.80(0.56$ to 1.18$)$ & 0.268 \\
\hline \multicolumn{5}{|l|}{ Gestational age } \\
\hline Antenatal & $337(98.5)$ & $151(95.6)$ & Ref & 0.055 \\
\hline Postpartum & $5(1.5)$ & $7(4.4)$ & $3.12(0.97$ to 10.00$)$ & \\
\hline \multicolumn{5}{|l|}{ Antenatal care } \\
\hline Inadequate & $114(3.3)$ & $61(38.6)$ & & 0.251 \\
\hline Adequate & $228(66.7)$ & 97 (61.4) & $0.80(0.54$ to 1.17$)$ & \\
\hline \multicolumn{5}{|l|}{ Looks Unwell } \\
\hline No & 334 (97.7) & $134(87.8)$ & Ref & $<0.001$ \\
\hline Yes & $8(2.3)$ & $24(15.2)$ & 7.48 (3.28 to 17.06$)$ & \\
\hline \multicolumn{5}{|c|}{ Neurological Status } \\
\hline Alert & $342(100)$ & $151(95.6)$ & & \\
\hline Verbal & 0 & $4(2.5)$ & NA & - \\
\hline Pain & 0 & $2(1.3)$ & NA & - \\
\hline
\end{tabular}




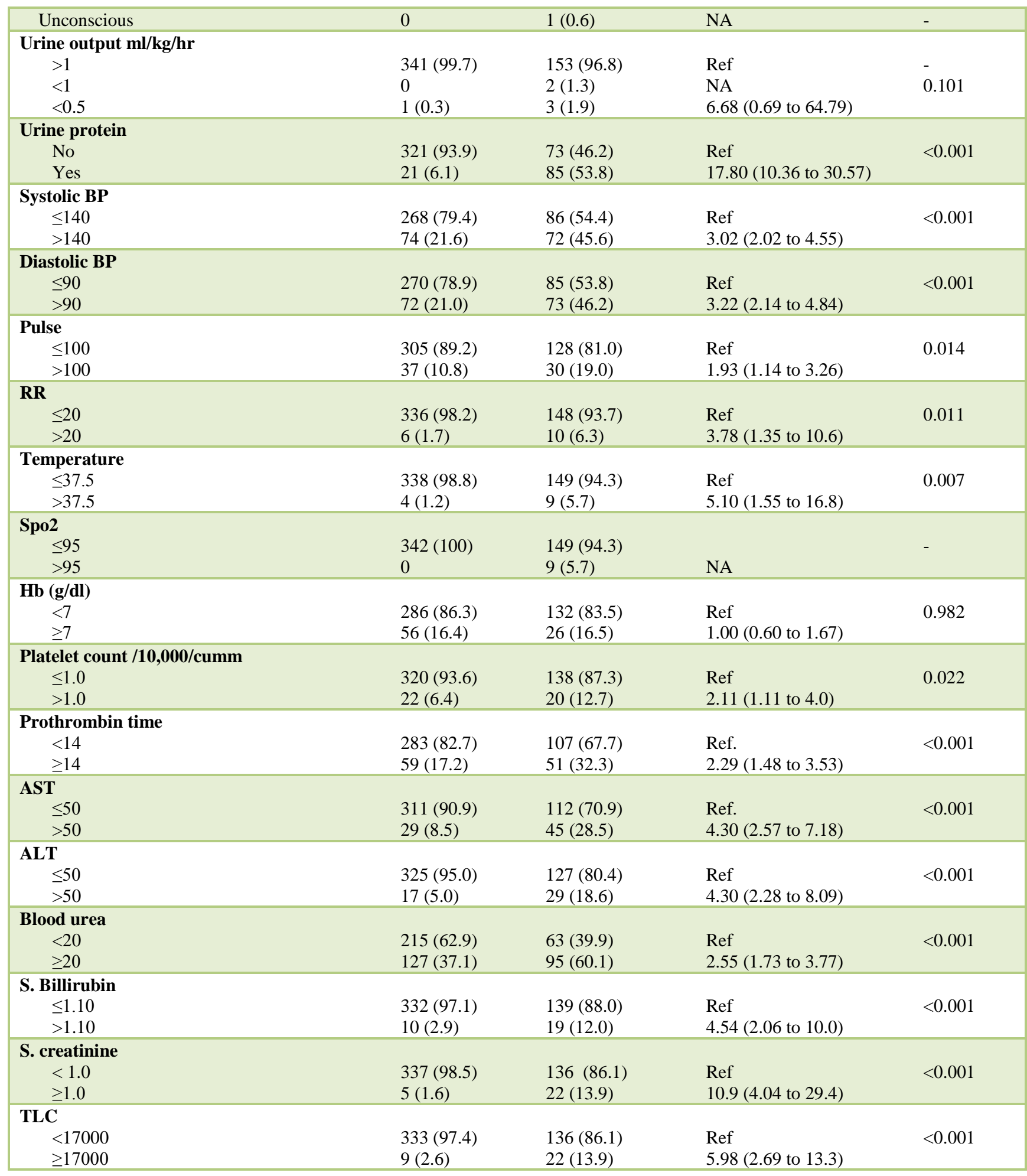

The risk factors observed in our study population were hypertension in $50.2 \%$, anemia in $24.6 \%$, heart disease in $17.4 \%$, diabetes mellitus in $6.6 \%$ and antepartum haemorrhage in $8.4 \%$. Some patients had more than one risk factor.

In our study SAMO was observed in 158 women which included near miss morbidity $(\mathrm{n}=131)$, ICU admission without miss morbidity $(\mathrm{n}=4)$ and maternal mortality $(n=23)$ which. The most common cause of near miss maternal morbidity in our study was hypertensive disorder of pregnancy in $62.7 \%$ followed by major obstetric hemorrhage in $18.9 \%$. There were 23 maternal deaths in our study and most common cause was obstetric hemorrhage in $34.7 \%$. 
Table 1 shows association of different demographic, physiological and biochemical parameters with SAMO.

However, SAMO did not show any association with age and socioeconomic status. Among physiological parameters blood pressure, pulse rate, temperature and oxygen saturation showed association with SAMO in bivariable analysis.

Table 2: Maternal Early Warning Score [MEWS].

\begin{tabular}{|c|c|c|c|c|c|c|c|c|}
\hline & \multicolumn{2}{|l|}{ SAMO } & \multicolumn{2}{|c|}{ Unadjusted } & \multicolumn{2}{|l|}{ Adjusted } & \multirow[b]{2}{*}{ Coefficient } & \multirow[b]{2}{*}{ Score assign } \\
\hline & $\begin{array}{l}\text { No } \\
(n=342)\end{array}$ & $\begin{array}{l}\text { Yes } \\
(n=158)\end{array}$ & $\begin{array}{l}\text { OR } \\
(95 \% \\
\text { CI })\end{array}$ & P-value & $\begin{array}{l}\text { OR } \\
(\mathbf{9 5 \%} \mathrm{CI})\end{array}$ & P-value & & \\
\hline Urine Protein & & & Ref & & Ref. & & & \\
\hline No & $321(93.9)$ & $73(46.2)$ & 17.80 & & 22.9 & & & \\
\hline Yes & $21(6.1)$ & $85(53.8)$ & $\begin{array}{l}(10.36 \text { to } \\
30.57)\end{array}$ & $<0.001$ & $\begin{array}{l}(13.01 \text { to } \\
40.35)\end{array}$ & $<0.001$ & 3.13 & 3 \\
\hline Temperature & & & Ref & & Ref. & & & \\
\hline$\leq 37.5$ & $338(98.8)$ & $149(94.3)$ & 5.10 & & 6.61 & & & \\
\hline$>37.5$ & $4(1.2)$ & $9(5.7)$ & $\begin{array}{l}(1.55 \text { to } \\
16.8)\end{array}$ & 0.007 & $\begin{array}{l}\text { (1.81 to } \\
24.17)\end{array}$ & 0.004 & 1.89 & 2 \\
\hline Pulse & & & Ref & & Ref. & & & \\
\hline$<99$ & $305(89.2)$ & $128(81.0)$ & 1.93 & & 3.34 & & & \\
\hline$\geq 100$ & $37(10.8)$ & $30(19.0)$ & $\begin{array}{l}\text { (1.14 to } \\
3.26)\end{array}$ & $<0.001$ & $\begin{array}{l}\text { (1.82to } \\
6.11)\end{array}$ & $<0.001$ & 1.20 & 1 \\
\hline & & & & & & & Total & 6 \\
\hline
\end{tabular}

Table 3: Maternal Risk Prediction Score [MRPS].

\begin{tabular}{|c|c|c|c|c|c|c|c|c|}
\hline & \multicolumn{2}{|l|}{ SAMO } & \multicolumn{2}{|l|}{ Unadjusted } & \multicolumn{3}{|l|}{ Adjusted } & \multirow{2}{*}{$\begin{array}{l}\text { Sco } \\
\text { re } \\
\text { ass } \\
\text { ign }\end{array}$} \\
\hline & $\begin{array}{l}\text { No } \\
(\mathrm{N}=342)\end{array}$ & $\begin{array}{l}\text { Yes } \\
(N=158)\end{array}$ & OR $(95 \%$ CI $)$ & $\begin{array}{l}\text { P- } \\
\text { value }\end{array}$ & OR $(95 \%$ CI $)$ & $\begin{array}{l}P \text { - } \\
\text { value }\end{array}$ & Coefficient & \\
\hline $\begin{array}{l}\text { Urine Protein } \\
\text { No } \\
\text { Yes }\end{array}$ & $\begin{array}{l}321(93.9) \\
21(6.1)\end{array}$ & $\begin{array}{l}73(46.2) \\
85(53.8)\end{array}$ & $\begin{array}{l}\text { Ref } \\
17.80(10.36 \\
\text { to } 30.57)\end{array}$ & $<0.001$ & $\begin{array}{l}\text { Ref. } \\
30.33(16.33 \\
\text { to } 56.32)\end{array}$ & $<0.001$ & 3.41 & 5 \\
\hline $\begin{array}{c}\text { S. creat } \\
\quad<1.0 \\
\geq 1.0\end{array}$ & $\begin{array}{l}337(98.5) \\
5(1.6)\end{array}$ & $\begin{array}{l}136(86.1) \\
22(13.9)\end{array}$ & $\begin{array}{l}\text { Ref } \\
10.9(4.04 \text { to } \\
29.4)\end{array}$ & $<0.001$ & $\begin{array}{l}\text { Ref. } \\
5.99 \text { ( } 1.72 \text { to } \\
20.83)\end{array}$ & 0.005 & 1.79 & 3 \\
\hline $\begin{array}{c}\text { Temperature } \\
\qquad 37.5 \\
>37.5\end{array}$ & $\begin{array}{l}338(98.8) \\
4(1.2)\end{array}$ & $\begin{array}{l}149(94.3) \\
9(5.7)\end{array}$ & $\begin{array}{l}\text { Ref } \\
5.10(1.55 \text { to } \\
16.8)\end{array}$ & 0.007 & $\begin{array}{l}\text { Ref. } \\
5.62(1.17 \text { to } \\
26.96)\end{array}$ & 0.031 & 1.12 & 3 \\
\hline $\begin{array}{r}\text { ALT } \\
\leq \mathbf{5 0} \\
>\mathbf{5 0}\end{array}$ & $\begin{array}{l}325(95.0) \\
17(5.0)\end{array}$ & $\begin{array}{l}127(80.4) \\
29(18.6)\end{array}$ & $\begin{array}{l}\text { Ref } \\
4.30(2.28 \text { to } \\
8.09)\end{array}$ & $<0.001$ & $\begin{array}{l}\text { Ref. } \\
3.37 \text { (1.41 to } \\
8.00)\end{array}$ & 0.006 & 1.21 & 2 \\
\hline $\begin{array}{l}\text { Pulse } \\
\quad<99 \\
\geq 100\end{array}$ & $\begin{array}{l}305(89.2) \\
37(10.8)\end{array}$ & $\begin{array}{l}128(81.0) \\
30(19.0)\end{array}$ & $\begin{array}{l}\text { Ref } \\
1.93(1.14 \text { to } \\
3.26)\end{array}$ & 0.014 & $\begin{array}{l}\text { Ref. } \\
3.48 \text { ( } 1.73 \text { to } \\
6.97)\end{array}$ & $<0.001$ & 1.24 & 2 \\
\hline $\begin{array}{l}\text { S. Bil } \\
\qquad 1.10 \\
>1.10\end{array}$ & $\begin{array}{l}332(97.1) \\
10(2.9)\end{array}$ & $\begin{array}{l}139(88.0) \\
19(12.0)\end{array}$ & $\begin{array}{l}\text { Ref } \\
4.54(2.06 \text { to }\end{array}$ & $<0.001$ & $\begin{array}{l}\text { Ref. } \\
3.22 \text { (1.12 to } \\
9.22)\end{array}$ & 0.029 & 1.17 & 2 \\
\hline
\end{tabular}




\begin{tabular}{|c|c|c|c|c|c|c|c|c|}
\hline & & & 10.0) & & & & & \\
\hline \multirow{4}{*}{$\begin{array}{c}\text { Blood urea } \\
\quad<20 \\
\geq 20\end{array}$} & & & & & & & & \\
\hline & $215(62.9)$ & $63(39.9)$ & 2.55 (1.73 to & & 1.95 ( 1.15 to & & & \\
\hline & $127(37.1)$ & $95(60.1)$ & $3.77)$ & $<0.001$ & 3.29) & 0.012 & 0.69 & 1 \\
\hline & & & & & & & Sore Total & 18 \\
\hline
\end{tabular}

Table 4: Comparison of observed and predicted percentage of SAMO at different score values by Maternal Early warning score and maternal risk prediction score.

\begin{tabular}{|c|c|c|c|c|c|c|c|}
\hline \multicolumn{4}{|c|}{ Maternal Early Warning Score [MEWS] } & \multicolumn{4}{|c|}{ Maternal Risk Prediction Score [MRPS] } \\
\hline $\begin{array}{l}\text { Score } \\
\text { value }\end{array}$ & $\begin{array}{l}\text { No. of } \\
\text { subject } \\
\text { with specific } \\
\text { score }\end{array}$ & $\begin{array}{l}\text { Observed } \\
\text { Probability } \\
\text { of being } \\
\text { SAMO }\end{array}$ & $\begin{array}{l}\text { Predicted } \\
\text { Probability of } \\
\text { being SAMO }\end{array}$ & $\begin{array}{l}\text { Score } \\
\text { value }\end{array}$ & $\begin{array}{l}\text { No. of } \\
\text { subject } \\
\text { with specific } \\
\text { score }\end{array}$ & $\begin{array}{l}\text { Observed } \\
\text { Probability } \\
\text { of being } \\
\text { SAMO }\end{array}$ & $\begin{array}{l}\text { Predicted } \\
\text { Probability } \\
\text { of being } \\
\text { SAMO }\end{array}$ \\
\hline 0 & $328(65.6 \%)$ & $15 \%$ & $14 \%$ & 0 & $174(34.8 \%)$ & $7 \%$ & $7 \%$ \\
\hline 1 & $55(11.0 \%)$ & $33 \%$ & $32 \%$ & 1 & $111(22.2 \%)$ & $14 \%$ & $13 \%$ \\
\hline 2 & $6(1.2 \%)$ & $33 \%$ & $58 \%$ & 2 & $42(8.4 \%)$ & $24 \%$ & $23 \%$ \\
\hline 3 & $103(20.6 \%)$ & $80 \%$ & $79 \%$ & 3 & $35(7.0 \%)$ & $34 \%$ & $38 \%$ \\
\hline$\geq 4$ & $8(1.6 \%)$ & $100 \%$ & $92 \%$ & 4 & $7(1.4 \%)$ & $57 \%$ & $55 \%$ \\
\hline \multirow{3}{*}{\multicolumn{4}{|c|}{$\begin{array}{l}\text { AUROC }[\text { MEWS }]=0.789 \\
\text { AUROC }[\text { MRPS }]=0.861\end{array}$}} & 5 & $58(11.6 \%)$ & $71 \%$ & $71 \%$ \\
\hline & & & & 6 & $42(8.4 \%)$ & $79 \%$ & $83 \%$ \\
\hline & & & & $\geq 7$ & $31(6.2 \%)$ & $97 \%$ & $91 \%$ \\
\hline
\end{tabular}

Table 5: Comparison of performance of maternal early warning score and maternal risk prediction score at best cut-off.

\begin{tabular}{|lll|}
\hline & MEWS $\geq 1$ & MRPS $\geq 2$ \\
\hline Sensitivity $(95 \% \mathrm{CI})$ & $69.60 \%(61.8 \%$ to $796.7 \%)$ & $82.3 \%(75.4 \%$ to $87.9 \%)$ \\
\hline Specificity(95\% CI) & $81.90 \%(77.4 \%$ to $58.8 \%)$ & $75.1 \%(70.2 \%$ to $79.6 \%)$ \\
\hline Positive Likelihood ratio $(95 \% \mathrm{CI})$ & $3.84(3$ to 4.92$)$ & $3.31(2.72$ to 4.04$)$ \\
\hline Negative Likelihood ratio $(95 \% \mathrm{CI})$ & $0.371(0.292$ to 0.472$)$ & $0.236(0.168$ to 0.332$)$ \\
\hline Odds ratio $(95 \% \mathrm{CI})$ & $10.3(6.69$ to 16$)$ & $14(8.74$ to 22.6$)$ \\
\hline Positive predictive value $(95 \% \mathrm{CI})$ & $64 \%(56.3 \%$ to $71.1 \%)$ & $60.5 \%(53.6 \%$ to $67 \%)$ \\
\hline Negative predictive value $(95 \% \mathrm{CI})$ & $85.40 \%(81.1 \%$ to $89 \%)$ & $90.2 \%(86.1 \%$ to $93.4 \%)$ \\
\hline
\end{tabular}

The bedside tests hemoglobin level and proteinuria $\geq+1$ were assessed and out of which proteinuria was found to be predictor of adverse outcome. When all these significant parameters were put in multivariate analysis, we were left with only three parameters viz. temperature, pulse rate and urine protein which were used in MEWS (Table 2). MEWS at score value of $\geq 1 / 6$ was found to have sensitivity of $70 \%$ and specificity of $82 \%$ in predicting adverse outcome with AUROC of 0.76 .

Neurological status measured by AVPU system (A-alert, V-response to verbal coomends, P-response to painful stimuli and U-unconscious), was found to be perfect predictor and all women who were not alert had SAMO, and could not be included in score.

Among biochemical parameters platelet count $<100,000 / \mathrm{mm} 3$,total leucocyte count $\geq 17000 / \mathrm{mm}^{3}$, Prothrombin time $\geq 14$, liver enzymes - ALT and AST $\geq$ 50 ,blood urea $\geq 20 \mathrm{mg} / \mathrm{dl}$, serum bilirubin $\geq 1.1$, serum creatinine $\geq 1 \mathrm{mg} / \mathrm{dl}$ and proteinuria were found to statistically association with SAMO in bi-variable analysis. We assessed all significant physiological and biochemical parameters via multivariate analysis to produce a Maternal risk prediction score [MRPS] which included following 7 parameters: temperature, pulse rate, urine protein, blood urea, serum creatinine, serum bilirubin and ALT (Table 3). When comparison of performance of MEWS and MRPS was carried out, this MRPS at value $\geq 2 / 18$ has sensitivity of $82 \%$ and specificity of $75 \%$ in predicting SAMO (Table 4 and 5).

\section{DISCUSSION}

Preeclampsia leads to increased perinatal morbidity and early warning scores are clinical tools to predict any deterioration or improvement in patient condition. Higher scores are associated with a need for further treatment or escalation to intensive care unit (ICU) or high dependency unit (HDU) care. All these early warning scores have some defined threshold, once this cut off is reached, a mandatory action is initiated to expedite 
further assessment of the patient by a suitably qualified clinician. ${ }^{12}$ This early intervention at right time by a right person can reduce morbidity and mortality among patients.

Commonly included parameters in obstetric EWS are heart rate, respiratory rate, and blood pressure, level of consciousness, temperature, oxygen saturation and urine output. The use of variables in a warning score is based more on consensus by clinicians and studied in developed countries. But in LMIC some of these parameters may not be available at the time of admission in all centers due to logistics of manpower and equipments. ${ }^{5}$ Due to high prevalence of anemia simple bedside tests like urine protein and hemoglobin are very important from perspective Indian obstetric patients.

We devised a 'MEWS score' which included only 3 parameters that could be taken by even a nursing staff and doesn't require high level of expertise. The area under the curve for MEWS score was 0.76 which is much less than 0.96 (95\% CI-0.92-0.99) reported by Carle et al. ${ }^{13}$

The sensitivity of our MEWS for predicting SAMO at score $\geq 1$ was $70 \%$ with specificity of $82 \%$, positive predictive value (PPV) of $64 \%$ and negative predictive value NPV of $84 \%$ as compared to a study conducted by Singh et al, who reported the sensitivity of $89 \%$, specificity 79\%, PPV- 39\% (95\% CI 32-46\%) and NPV of $98 \%$ (95\% CI $96-99 \%)$.Our score simple with less variables thus easy to performand has higher PPV. ${ }^{12}$

Role of laboratory tests as a predictor of patient outcome has been recently reviewed in various studies. ${ }^{14,15}$ These are not diagnostic tools, and it is very important to diagnose the underlying cause of the metabolic abnormality. However, they can have a role in identification of the sick patient and as such may be employed as a triage tool. The clinician should be aware that minor abnormalities in these metabolic and biochemical markers signify the potential for deterioration and mortality and thus may warrant urgent action. In our study we used common biochemical test along with physiological parameters to assess clinical outcome. Our maternal risk prediction score had AUROC of 0.86 and it was found to be superior than the MEWS who's AUROC was 0.78. A study by Loekito et al, which used laboratory tests such as serum levels of sodium, potassium, chloride, blood urea, serum creatinine, serum albumin, total bicarbonate, bilirubin, alkaline phosphatase, alanine aminotransferase, and gammaglutamyl transferase. They found that multivariate logistic modelling achieved an AUROC (95\% CI) of 0.87 (0.85-0.89) for the prediction of imminent death, defined as thepatient's death either on the same day or during the following calendar day. A similar AUROC (95\%CI) of $0.88(0.85-0.90)$ was obtained by employing their method in a second hospital. ${ }^{16,17}$
Out of all biochemical parameters urine protein was found to be major predictor of bad outcome with OR (95\% CI):30.33 (16.33-56.32). It may be because the most common risk factor for maternal morbidity and mortality in our study was hypertensive disorder of pregnancy. It was followed by serum creatinine with OR (95\%CI):5.99 (1.72 to 20.83).Among physiological parameters, temperature was the most predictive measure of patient outcome with OR (95\%CI):5.62 (1.17-26.96) Our study analysed data from the first routinely collected laboratory test result taken during the hospital stay, which whereas close to admission as possible and, therefore, least likely have been influenced by prior therapy.

The most common cause of near miss maternal morbidity in our study was hypertensive disorder of pregnancy $(62.7 \%)$ followed by major obstetric hemorrhage $(18.9 \%)$ whereas in the study by Singh et al, the most common morbidity was hemorrhage $(43 \%)$ followed by hypertensive disease of pregnancy $(31 \%)$ and suspected infection $(20 \%){ }^{12}$

The most common cause of maternal death in our study was obstetric hemorrhage $(34.7 \%)$ whereas Saravana Kumar $\mathrm{K}$ et al, reported cardiac disease (22.2\%) as most common cause of maternal death. ${ }^{18}$

The limitation of this study was that it was a single centre study, small sample size, results not validated. The strength of this study is that it considers feasibility in terms of real life application in LMICs. More studies are required to refine the variables in these scores and implications of trigger in terms of logistics in LMICs where patient healthcare provider ratios are likely to be low.

\section{CONCLUSION}

MEWS based on physiological parameters at score value of $\geq 1 / 6$ was found to have sensitivity of $70 \%$ and specificity of $82 \%$ with AUROC of 0.76 , whereas MRPS which incorporated common laboratory parameters in addition to physiological parameters have better performance at value $\geq 2 / 18$ (cut off AUROC 0.79) and sensitivity of $82 \%$ and specificity of $75 \%$ in predicting SAMO.

\section{Funding: No funding sources}

Conflict of interest: None declared

Ethical approval: The study was approved by the Institutional Ethics Committee

\section{REFERENCES}

1. Royal college of physicians. National Early warning score (NEWS): Standardizing the Assessment of acute illness severity in the NHS. Report of a working party. London: RCP, 2012 .Available from www.rcpiondon.ac.uk/resources. (Last assessed on 25th November 2013). 
2. Carle C, Alexander P, Columb M, Jpohal J. Design and internal validation of an obstetric early warning score: secondary analysis of the intensive care National Audit and research centre case Mix programme database. Anaesthesia. 2013;68:354-67.

3. Swanton RDJ, Al-Rawai S, Wee MYK. A national survey of obstetric early warning system in UK. Int J Obst Anesth. 2009;18:253-7.

4. All Wales Consensus paper 2012. Available at; www.1000Livesplus.wales.nhs.uk. (Last assessed on 25th November 2013).

5. Beane A, De Silva AP, De Silva N. 'Evaluation of feasibility and performance of early warning scores to identify patients at risk of adverse outcomes in a low-middle income setting'. BMJ open. 2018; 019387.

6. Perera YS, Ranasinghe $\mathrm{P}$, Adikari AMMC, Welivita WDTS, Perera WME, Wijesundara WMDR, et al. The value of the modified early warning score and biochemical parameters as predictors of patient outcome in acute medical admissions: A prospective study. Acute Med. 2011;10:126-32.

7. Milman N, Bergholt T, Byg KE. Reference intervals for hematological variables during normal pregnancy and postpartum in 434 healthy Danish women. Eur J Haematol. 2007;79:39.

8. Liu XH, Jiang YM, Shi H. Prospective, sequential, longitudinal study of coagulation changes during pregnancy in Chinese women. Int J Gynaecol Obstet. 2009;105(3):240.

9. Bacq Y, Zarka O, Brechot JF. Liver function tests in normal pregnancy: A prospective study of 102 pregnant women and 102 matched controls. Hepatology. 1996;23:1030.

10. Larsson A, Palm M, Hansson LO. Reference values for clinical chemistry tests during normal pregnancy. BJOG. 2008;115:874.

11. Brace V, Penney G, Hall M. Quantifying severe maternal morbidity: a Scottish population study. BJOG. 2004;111:481-4.
12. Singh S, McGlennan A, England A, Simons R. A Validation study of the CEMACH recommended MEOWS. Anesthesia. 2012;67:12-8.

13. Carle C, Pohal J, Columb M, Alexander. 'Design and internal validation of obstetric early warning score: secondary analysis of intensive care National Audit and research centre case mix programme database.' Anesthesia. 2013;68, 354-67.

14. O’Sullivan E, Callely E, O'Riordan D, Bennett K, Silke B. Predicting outcomes in emergency medical admissions - role of laboratory data and comorbidity. Acute Medicine. 2012;11(2):59.

15. Romero-Ortuno R, Silke B. Use of a laboratory only score system to define trajectories andoutcomes of older people admitted to the acute hospital as medical emergencies. Geriatr Gerontol Int. 2012. doi: 10.1111/j.1447-0594.2012.00917.x.

16. Loekito E, Bailey J, Bellomo R. Common laboratory tests predict imminent death in ward patients. Resuscitation. 2013;84:280-5.

17. Loekito E, Bailey J, Bellomo R. Common laboratory tests predict imminent medical emergency team calls, intensive care unit admission or death in emergency department patients. Emergency Medicine Australasia. 2013;25:132-9.

18. Saravanakumar K. High dependency care in an obstetric setting in UK Anesthesia. Anesthesia. 2008;63(10):1081-6.

Cite this article as: Rani R, Meena SB, Yadav CP, Goswami D, Tripathi R, Rathore AM. Prediction of severe adverse maternal outcome in women admitted in obstetric ward using physiological and biochemical parameters. Int J Reprod Contracept Obstet Gynecol 2019;8:2019-26. 